\title{
Regulation of gonadotrophin secretion by inhibin, testosterone and gonadotrophin-releasing hormone in pituitary cell cultures of male monkeys
}

\author{
U Fingscheidt, G F Weinbauer ${ }^{1}$, H L Fehm and E Nieschlag ${ }^{1}$ \\ Medical Clinic I, Medical University of Lübeck, D-23538 Lübeck, Germany and ${ }^{1}$ Institute of Reproductive Medicine of the University, \\ D-48129 Münster, Germany \\ (Requests for offprints should be addressed to U Fingscheidt, Medical Clinic I, Medical University of Lübeck, Ratzeburger Allee 160, \\ D-23538 Lübeck, Germany)
}

\begin{abstract}
The effects of bovine inhibin, testosterone and GnRH on gonadotrophin secretion by primate pituitary cells were characterized in vitro using pituitaries from six male rhesus monkeys and one male cynomolgus monkey. The effect of inhibin on basal secretion of FSH and LH was investigated. Dose-response curves in monkeys and rats were compared. GnRH dose-response curves in the presence and absence of testosterone were also examined in monkeys.

In monkey pituitary cells, testosterone at a concentration of $10^{-7} \mathrm{M}$ had no effect on $\mathrm{LH}$ or FSH secretion. Inhibin suppressed FSH secretion to $50 \cdot 8 \%$ of that of controls with no effect on LH. In rats, FSH secretion was
\end{abstract}

suppressed to $45 \cdot 0 \%$ of that of controls with a median effective dose $\left(\mathrm{ED}_{50}, 95 \%\right.$ range) of 1.298 (1.064-1.584) $\mathrm{U} / \mathrm{ml}$, compared with $1.024(0 \cdot 7204-1 \cdot 455) \mathrm{U} / \mathrm{ml}$ in monkeys. In monkey pituitary cells, LH release was stimulated 9.9-fold and FSH 3.3-fold by GnRH. Testosterone had no effect on basal or GnRH-stimulated gonadotrophin release. These results support the view that the pituitary is not the target organ for the negative feedback action of testosterone in the male. In vitro, inhibin is the major regulator of FSH secretion at the pituitary level.

Journal of Endocrinology (1998) 159, 103-110

\section{Introduction}

According to the classical inhibin hypothesis, secretion of follicle-stimulating hormone (FSH) is regulated by a dual feedback system of two testicular hormones: inhibin and testosterone. The main biological action of inhibin is the suppression of gonadotrophins, predominantly FSH, at the pituitary level. Since inhibin has become available in purified or recombinant preparations (Mason et al. 1985a,b, Forage et al. 1986, Mayo et al. 1986), this effect on FSH has been proved in different in vitro systems of cultured pituitary cells of rats (Scott et al. 1980, Farnworth et al. 1988) and sheep (Tsonis et al. 1986). Later, inhibin was administered in vivo to rats (Rivier et al. 1991), sheep (Mercer et al. 1987) and monkeys (Stouffer et al. 1994) and the suppressive action on FSH confirmed. A recent study based on the experimental model of the hypophysiotropic clamp, which eliminates feedback effects other than those at the pituitary site, suggested that suppression of FSH is mediated by inhibin in monkeys and that testosterone has no effect on the pituitary gland (Majumdar et al. 1995). Although there is little doubt about the effect of inhibin on $\mathrm{FSH}$, direct proof that it acts at the pituitary cell in primates is lacking. We therefore established a cell culture system for monkey cells to characterize the effect of inhibin on pituitary cells in vitro. Furthermore, we repeated the experiment with rat pituitary cells to define possible interspecies differences between rats and monkeys with regard to the action of inhibin.

The control of FSH by inhibin is supplemented by the negative feedback action of testosterone on FSH. The degree to which either the hypothalamus or pituitary contribute to the effect of testosterone has not been defined thoroughly. Studies in different experimental models and different species have led to conflicting results. Dubey et al. (1987) showed that neither testosterone nor oestradiol had any negative feedback action at the pituitary in monkeys in vivo. In vitro, on the other hand, a suppressive effect of testosterone on luteinizing hormone (LH) secretion of pituitary cells could be demonstrated in rats (Kamel et al. 1987). Studies in men with hypothalamic hypogonadism treated with pulsatile gonadotrophinreleasing hormone $(\mathrm{GnRH})$ confirmed this suppressive effect of testosterone on $\mathrm{LH}$ and FSH at the pituitary site (Bagatell et al. 1994). In another model of hypothalamuspituitary-disconnected rams, both testosterone and inhibin decreased FSH in the serum under stimulation with GnRH (Tilbrook et al. 1993).

Our cell culture system was also used to characterize the effects of testosterone on basal and GnRH-stimulated 
gonadotrophin secretion of primate pituitary cells in vitro.

\section{Materials and Methods}

\section{Animals}

Six intact adult male rhesus monkeys (Macaca mulatta) and one adult male cynomolgus monkey (Macaca fascicularis) were used for this study. The mean \pm s.D. body weight of the rhesus monkeys was $12.6 \pm 1.6 \mathrm{~kg}$ and the weight of the cynomolgus monkey was $4.7 \mathrm{~kg}$. The animals were maintained in a controlled environment, with a $12 \mathrm{~h}$ light/12 $\mathrm{h}$ darkness photoperiod as described previously (Weinbauer et al. 1984). Pelleted monkey diet supplemented with fresh fruit was provided twice daily, and tap water was available ad libitum. Testosterone and bioactive LH as well as testicular volume, body weight and general health of the animals were normal.

A total of 60 adult male Wistar rats weighing 180-220 g were housed in cages (five animals/cage) under controlled temperature $\left(23^{\circ} \mathrm{C}\right)$ and lighting conditions (12 h light/ $12 \mathrm{~h}$ darkness) with free access to pelleted food and tap water.

Maintenance and handling of monkeys and rats complied with the German Federal Law for Care and Use of Laboratory Animals.

\section{Preparation of pituitaries}

In monkeys, five independent preparations of pituitaries were carried out. The first three were from individual animals, one cynomolgus and two rhesus monkeys. In each of the other two experiments, pituitary cells from two rhesus monkeys were pooled to increase the number of wells for different doses of substances tested. In addition, three independent experiments in rats with 20 rats per preparation of pituitary cells were carried out. The experiments described required two rats per experiment. To minimize the interexperimental variation, 20 rats were used in every preparation. Remaining cells were used for calibration of inhibin standards and for a study on the effect of basal GnRH on gonadotrophins (results not shown). Monkeys were anaesthetized with ketamine hydrochloride (20 mg/kg; Ketavet; Parke-Davis, München, Germany) and killed with $\mathrm{CO}_{2}$. Rats were killed with $\mathrm{CO}_{2}$ and decapitated. Pituitaries were removed immediately after death and transported at $37^{\circ} \mathrm{C}$ in sterile PBS containing $100 \times 10^{3} \mathrm{U} / 1$ penicillin (Serva, Heidelberg, Germany), $100 \mathrm{mg} / 1$ streptomycin (Serva), $2 \cdot 7 \mathrm{~g} / 1$ glucose and $0 \cdot 3 \%$ BSA (Behring, Marburg, Germany). A period of $15 \mathrm{~min}$ elapsed between the death of the animals and the beginning of cell preparation under a laminar flow hood.

\section{Cell culture}

Cells were prepared under sterile conditions as described previously (Hyde et al. 1982), with modifications. Briefly, pituitaries were rinsed in PBS and cut into approximately $1 \mathrm{~mm}^{3}$ pieces using a scalpel. Incubation with trypsin (Type III; $1.5 \mathrm{~g} / 1$; Sigma, München, Germany) and DNase (Type I; $100 \mathrm{mg} / \mathrm{l}$; Sigma) in PBS was carried out for $30 \mathrm{~min}$ at $37^{\circ} \mathrm{C}$, followed by a further incubation with DNase $(200 \mathrm{mg} / \mathrm{ml})$ in PBS for $4 \mathrm{~min}$ and EDTA $\left(2 \times 10^{-3} \mathrm{M}\right)$ in PBS without $\mathrm{Ca}^{2+}$ and $\mathrm{Mg}^{2+}$ and for $5 \mathrm{~min}$. Pituitary cells were then dispersed mechanically by repeated aspiration with a Pasteur pipette in DNase $(100 \mathrm{mg} / \mathrm{l})$ in PBS without $\mathrm{Ca}^{2+}$ and $\mathrm{Mg}^{2+}$. This process was repeated 7 times for rat cells and 20 times for monkey cells. The dispersion was followed by centrifugation at $200 \mathrm{~g}$ for $10 \mathrm{~min}$ and resuspension in Dulbecco's modified Eagle's medium (DMEM) containing $100 \times 10^{3} \mathrm{U} / 1$ penicillin, $100 \mathrm{mg} / 1$ streptomycin, $1 \cdot 2 \mathrm{~g} / 1 \mathrm{NaHCO}_{3}$, $10 \mathrm{ml}$ non-essential amino acid solution (Serva), $1 \times 10^{-3}$ M L-glutamine (Serva) and 10\% fetal calf serum (Sigma) which had been pretreated with charcoal and dextran to remove steroids. Cells were counted, and viability was determined by measuring trypan blue exclusion. The cell suspension was diluted to $100 \times 10^{6}$ cells $/ 1$ and distributed on 24-well culture plates (Costar, Cambridge, MA, USA) with $50 \times 10^{3}$ cells/well. The culture medium volume was $500 \mu \mathrm{l} /$ well. Hormone levels were multiplied by a factor of 20 to convert units from $\mathrm{ng} / 50 \times 10^{3}$ cells to $\mathrm{ng} / 10^{6}$ cells. Cell preparation was followed by a preincubation for $48 \mathrm{~h}$ at $37^{\circ} \mathrm{C}, 98 \%$ humidity, $5 \% \mathrm{CO}_{2}$ in air. After $48 \mathrm{~h}$ the medium was changed, and, in six wells, the cells were detached by incubation with EDTA in PBS without $\mathrm{Ca}^{2+}$ and $\mathrm{Mg}^{2+}$, and stained with trypan blue to determine viability. The same procedure was carried out after collection of medium at the end of the experiments. In addition, media collected from six dishes were centrifuged at $200 \mathrm{~g}$ for $10 \mathrm{~min}$ and resuspended in PBS without $\mathrm{Ca}^{2+}$ and $\mathrm{Mg}^{2+}$, stained with trypan blue and examined microscopically. Media were collected and stored at $-20^{\circ} \mathrm{C}$ until determination of FSH and LH by RIA.

\section{Experimental protocol}

Effect of inhibin on FSH and LH secretion in monkeys and rats The effect of incubation with inhibin in increasing doses on basal FSH and $\mathrm{LH}$ release was studied during an incubation period of $48 \mathrm{~h}$. Highly purified bovine inhibin with a molecular mass of $31 \mathrm{kDa}$ (D M de Kretser, Clayton, Vic, Australia) was dissolved after methanol precipitation in DMEM, and added to cell cultures in triplicate in doses from 0 to $20 \mathrm{U} / \mathrm{ml}$ after the preincubation for $48 \mathrm{~h}$. Inhibin had a specific activity of $750 \mathrm{U} / \mu \mathrm{g}$, and the concentration can thus be converted from $\mathrm{U} / 1$ to $\mathrm{nmol} / 1$ using the approximation: $1 \mathrm{U} / 1$ $\approx 43 \mathrm{nmol} / 1$ (Robertson et al. 1986). After $48 \mathrm{~h}$, medium was removed and frozen for assay of hormones. This experiment was carried out once in a cynomolgus monkey cell culture, three times in rhesus monkey cell culture, and three times in rat pituitary cell cultures. 
Effects of testosterone on basal and GnRHstimulated secretion of FSH and LH in monkeys The aim of this experiment was to determine the effects of testosterone on GnRH-stimulated secretion of gonadotrophins. After the preincubation of $48 \mathrm{~h}$, culture medium was removed and replaced with warm fresh medium containing either $0 \cdot 2 \%$ ethanol or testosterone $\left(10^{-7} \mathrm{M}\right.$; Sigma) in $0.2 \%$ ethanol. In three aliquots taken at the end of the experiment, testosterone was measured by luminescence assay and found to be $0.98 \times 10^{-7} \mathrm{M}$. After a further $44 \mathrm{~h}$, medium was replaced with one of the same composition (testosterone in ethanol or ethanol alone), and graded doses of GnRH $\left(0,10^{-11}, 10^{-9}, 10^{-7}\right.$ and $10^{-6} \mathrm{M}$; Relefact LHRH; Hoechst, Frankfurt, Germany) were added in $10 \mu \mathrm{l}$ PBS. After $4 \mathrm{~h}$ incubation with GnRH, medium was collected and stored for assay of hormones. This experiment was performed in triplicate and repeated twice.

\section{Hormone analysis}

Inhibin in the serum was measured in a double-antibody RIA validated for cynomolgus monkey, rat, human and bovine serum and follicular fluid (Fingscheidt et al. 1989). This RIA detected the 59 and $31 \mathrm{kDa}$ forms of dimeric inhibin and also reacted with the $\alpha$-subunit precursor protein pro- $\alpha$ C. Serial dilutions of rhesus monkey serum with a maximum volume of $100 \mu \mathrm{l}$ serum/tube were parallel to those of cynomolgus monkey serum. Samples were assayed in duplicate using $50 \mu \mathrm{l}$ serum/tube. The minimum detectable dose was $0 \cdot 2 \mathrm{U} / \mathrm{ml}$; the intra-assay coefficient of variation was $5 \cdot 5 \%$ at $0.35 \mathrm{U} / \mathrm{ml}$.

Monkey FSH in the medium was measured by a human FSH (NIAMDD hFSH-2):anti-ovine-FSH (H 31, NICHD) RIA system that employs a purified cynomolgus FSH preparation (WP-XV-104 C) as standard as described previously (Khan \& Diczfalusy 1983). The detection limit was $0 \cdot 2 \mathrm{ng} / \mathrm{ml}$, the interassay coefficient of variation $(n=6$, at $1.2 \mathrm{ng} / \mathrm{ml}$ ) was $8.2 \%$ and the intra-assay coefficient of variation was $6.5 \%$ at $1.2 \mathrm{ng} / \mathrm{ml}$. Serial dilutions of the medium paralleled those of the standard preparation.

Monkey LH in the medium was measured by a heterologous RIA using a cynomolgus LH preparation (WP-XV-63-2429) as tracer, anti-human chorionic gonadotrophin as antibody and LER 1909-2 as standard, as described previously (Kurshid et al. 1991). The detection limit of this assay was $0.3 \mathrm{ng} / \mathrm{ml}$, the interassay coefficient of variation $(n=6$, at $2 \cdot 2 \mathrm{ng} / \mathrm{ml})$ was $6.9 \%$ and the intraassay coefficient of variation was $5 \cdot 8 \%$ at $2 \cdot 2 \mathrm{ng} / \mathrm{ml}$. Serial dilutions of the medium paralleled those of the standard preparation.

Rat FSH $(\mathrm{rFSH})$ and rat $\mathrm{LH}(\mathrm{rLH})$ in the medium were measured using double-antibody RIAs based on reagents supplied by NIDDK rFSH:rFSH-S-9 and rLH:rLH-S-9, standards: RP-2, anti-rabbit globulin (donkey) second antibody RD-17 (Wellcome, Dartford, Kent, UK), by the method of Solano et al. (1979). The minimum detectable doses were $3 \mathrm{ng} / \mathrm{ml}(\mathrm{FSH})$ and $1 \mathrm{ng} / \mathrm{ml}(\mathrm{LH})$, interassay coefficients of variation were $7 \cdot 2 \%(\mathrm{rFSH})$ and $6 \cdot 1 \%$ $(\mathrm{rLH})$, and intra-assay coefficients of variation were $4 \cdot 3 \%$ $(\mathrm{rFSH})$ and $5 \cdot 1 \%(\mathrm{rLH})$.

Testosterone was measured by a luminescence immunoassay developed in our institute (Kreysing \& Nieschlag 1987). The detection limit of the assay was $0.27 \mathrm{mM}$, and intra-assay variation was $5 \cdot 3 \%$.

\section{Statistical analysis}

Each dose in the cell culture experiments was tested in triplicate, and medians of triplicate doses were calculated. For graphic representation of the data, means and standard deviation were computed from the three medians obtained from independent experiments.

Dose-response curves were fitted for the calculated medians of each of three identical experiments using the GraphPad Prism program to obtain values for median effective dose $\left(\mathrm{ED}_{50}\right)$, maximal suppression or stimulation (bottom or top) and 95\% ranges. Curves were compared using two-way multivariate analysis of variance (MANOVA) using the SPSS for Windows computer program. Differences between basal gonadotrophin secretion before stimulation with GnRH in testosteronetreated cell cultures of cynomolgus monkeys compared with controls were analysed using the $t$-test for independent samples (SPSS for Windows).

\section{Results}

Monkey pituitary cells were separated by an intensified mechanical method of dispersion. The yield of cells/ pituitary for rhesus monkeys was $(4.5 \pm 1 \cdot 2) \times 10^{6}$ cells (mean \pm S.E.M., $n=6$ ); viability was $92 \pm 4 \%$ (mean \pm S.E.M.). In the cynomolgus monkey pituitary cell culture, $3.6 \times 10^{6}$ cells/pituitary with a viability of $92 \%$ were obtained. For rats, $(3 \cdot 2 \pm 0 \cdot 2) \times 10^{6}$ cells/pituitary (mean \pm S.E.M.) with a viability of $96 \pm 2 \%$ (mean \pm s.E.M.) were obtained. Controls for cultures treated with testosterone, inhibin and/or GnRH at the end of one experiment showed no significant decrease in cell count or viability (at the beginning of the experiment $(105 \cdot 2 \pm 10) \times 10^{3}$ cells $/ \mathrm{ml}$ and $99 \pm 1 \%$ viable cells; after $48 \mathrm{~h}$ incubation with DMEM and change of medium at $44 \mathrm{~h}(101 \cdot 6 \pm 16) \times 10^{3}$ cells $/ \mathrm{ml}$ and $98 \pm 1 \%$ viable cells; after $48 \mathrm{~h}$ incubation with inhibin $(103 \cdot 2 \pm 9) \times 10^{3}$ cells $/ \mathrm{ml}$ and $97 \pm 2 \%$ viable cells; after incubation with testosterone and $\mathrm{GnRH}$ and one change of medium at $44 \mathrm{~h}(98 \cdot 6 \pm 12) \times 10^{3}$ cells and $97 \pm 3 \%$ viable cells). Medium from the preincubation phase contained debris in small amounts but no cells, and medium obtained during the experiment contained no debris or cells. FSH levels (triplicate wells in three independent experiments 


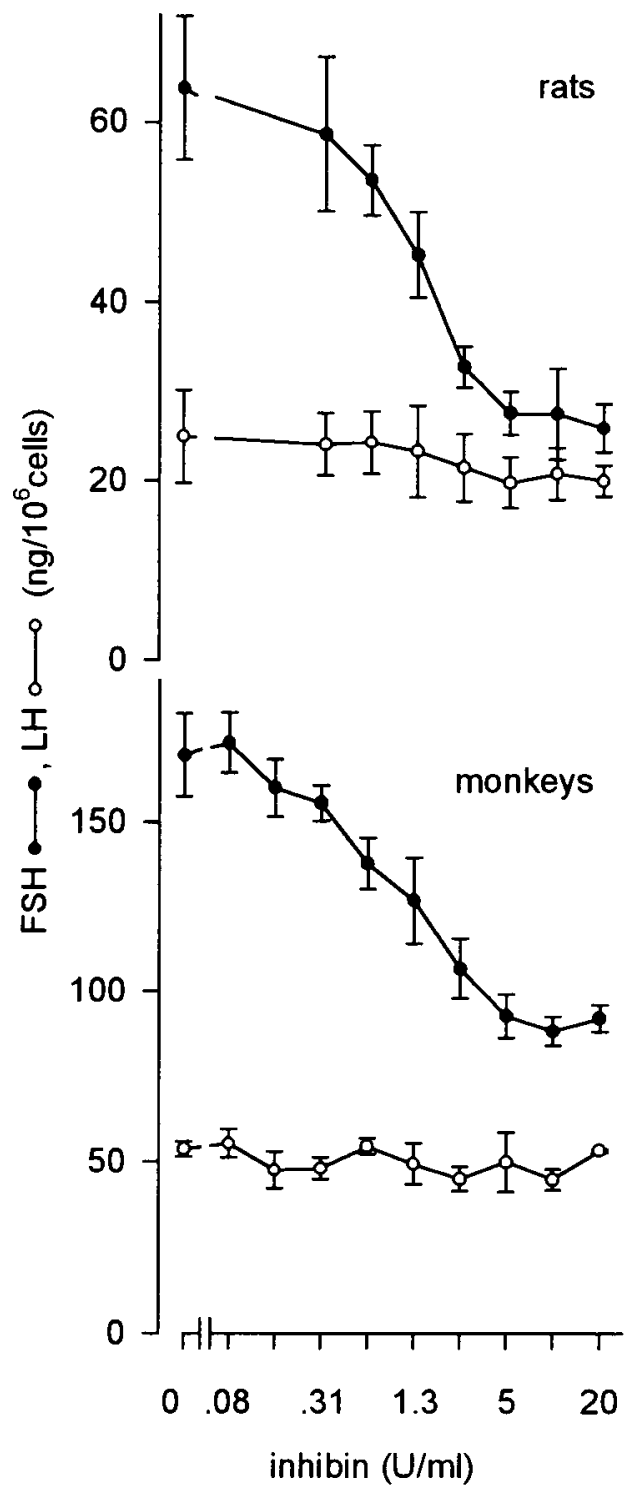

Figure 1 Effect of purified bovine inhibin on the secretion of FSH and LH in pituitary cell cultures of male rats (top) and rhesus monkeys (bottom). The results of three independent experiments (mean \pm S.D.) in each species are depicted.

$(n=3 \times 3))$ ranged from $159 \cdot 9$ to $194.5 \mathrm{ng} / 10^{6}$ cells for basal secretion and from $76 \cdot 3$ to $103 \cdot 8 \mathrm{ng} / 10^{6}$ cells for maximally suppressed secretion during the $48 \mathrm{~h}$ incubation.

Effects of inhibin on basal gonadotrophin secretion and cell content in monkeys and rats

Inhibin suppressed FSH secretion in rhesus monkey pituitary cell cultures in a dose-dependent manner to $50 \cdot 8 \%$ (95\% range $44 \cdot 7-56 \cdot 9)$ of controls (Fig. 1, bottom). The dose-response curve was of sigmoid shape, and the $\mathrm{ED}_{50}$

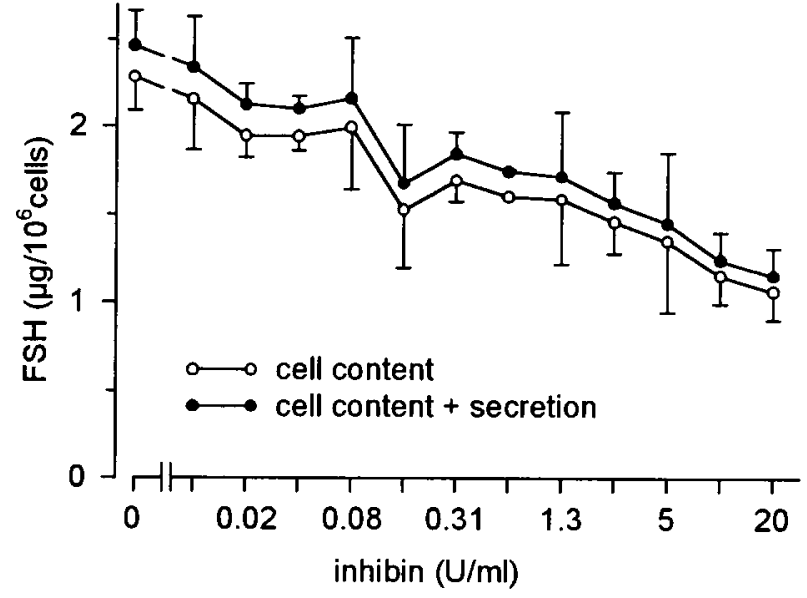

Figure 2 Effect of purified bovine inhibin on cell content of FSH and total FSH (secreted plus cell content) in pituitary cell cultures of five male rhesus monkeys. The results of three independent experiments (mean \pm S.D.) with cells from one or two monkeys are depicted.

was $1.024 \mathrm{U} / \mathrm{ml}$ (95\% range 0.7204 to $1 \cdot 455)$. The cell content of FSH and total FSH in the cell culture system at the end of the incubation were likewise decreased (Fig. 2). Levels of inhibin in the serum of normal male rhesus monkeys were determined as described previously (Fingscheidt et al. 1989) in eight animals and were $2 \cdot 8$ $(0.7-4.9) \mathrm{U} / \mathrm{ml}$ (mean, 95\% range). Cell cultures of cynomolgus monkey pituitary cells showed comparable secretion of FSH with similar suppression (data not shown). No significant effect of inhibin on $\mathrm{LH}$ secretion in rhesus monkey pituitary cells could be detected $(P>0 \cdot 05$; ANOVA, followed by Tukey's test; Fig. 1, bottom). We observed no difference between the effect of inhibin on FSH and LH in monkey cell cultures and that in rat pituitary cell cultures (Fig. 1, top). In rats, FSH secretion was suppressed to $45 \cdot 0 \%$ (95\% range $40 \cdot 3-49 \cdot 6)$ of controls. The $\mathrm{ED}_{50}$ was $1.298 \mathrm{U} / \mathrm{ml}(95 \%$ range 1.064 to 1.584). Inhibin in the serum of male rats was determined in 49 rats in previous studies (Fingscheidt et al. 1990, Chandolia et al. 1991) and found to be $1 \cdot 0(0 \cdot 7-1 \cdot 2) \mathrm{U} / \mathrm{ml}$ (mean, 95\% range).

Effects of testosterone on basal and GnRH-stimulated secretion of FSH and LH in rhesus monkeys

Testosterone at a concentration of $10^{-7} \mathrm{M}$ had no significant effect on basal secretion of FSH or LH during the second preincubation phase of $44 \mathrm{~h}$ (Fig. 3), which followed the initial preincubation of $48 \mathrm{~h}$ ( $P>0 \cdot 05, t$-test). $\mathrm{GnRH}$ in graded doses, added during the final $4 \mathrm{~h}$ of this experiment, stimulated secretion of FSH to maximally $332 \cdot 7 \%$, and LH to $991 \cdot 3 \%$ of basal secretion. Testosterone at a concentration of $10^{-7} \mathrm{M}$ had no significant effect on GnRH-stimulated gonadotrophin secretion $(P>0 \cdot 05$, 

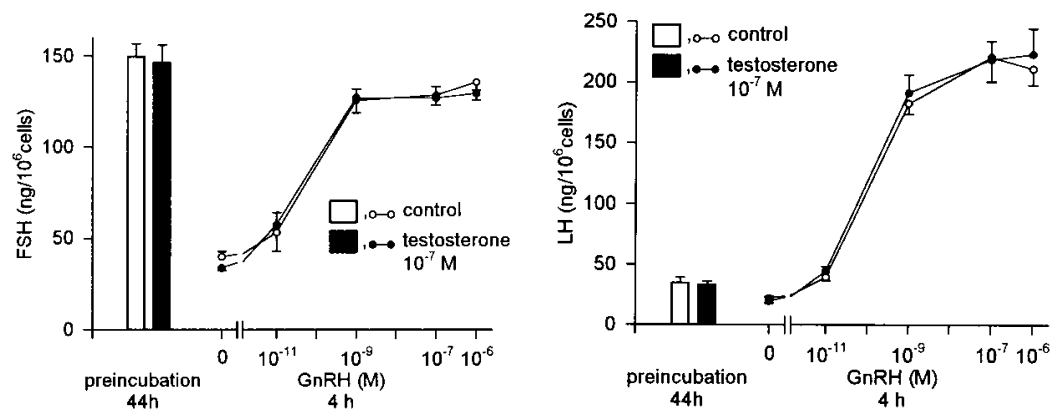

Figure 3 Effect of testosterone (solid bars) at a concentration of $10^{-7} \mathrm{M}$ on basal secretion of $\mathrm{FSH}$ (left) and $\mathrm{LH}$ (right) in rhesus monkey pituitary cell cultures during the preincubation period of $44 \mathrm{~h}$ compared with controls (open bars). After the preincubation phase, the medium was changed and GnRH was added. The curves on the right represent the effect of testosterone $\left(10^{-7} \mathrm{M}, \mathbf{0}\right)$ on $\mathrm{GnRH}$-stimulated release of FSH (left) and $\mathrm{LH}$ (right) during the following $4 \mathrm{~h}$ of incubation compared with controls $(\bigcirc)$. GnRH was added in graded doses from 0 to $10^{-6} \mathrm{M}$.

MANOVA). With no interaction, GnRH had a significant effect on FSH and LH $(P<0 \cdot 001$, MANOVA). The $\mathrm{ED}_{50}$, (95\% range) for stimulation of $\mathrm{FSH}$ by $\mathrm{GnRH}$ was $6.5 \times 10^{-11}\left(1.7 \times 10^{-11}-2.5 \times 10^{-10}\right) \mathrm{M}$. The corresponding $\mathrm{ED}_{50}$ for stimulation of $\mathrm{LH}$ by $\mathrm{GnRH}$ was higher: $1.6 \times 10^{-10}\left(7.6 \times 10^{-11}-3.2 \times 10^{-10}\right) \mathrm{M}$. Changing the culture medium after $44 \mathrm{~h}$ increased the basal LH-release rate from $3 \cdot 1$ to $21 \cdot 8 \mathrm{ng} / 10^{6}$ cells per $4 \mathrm{~h}$ and $\mathrm{FSH}$ secretion rose from 13.6 to $39 \cdot 7 \mathrm{ng} / 10^{6}$ cells per $4 \mathrm{~h}$.

\section{Discussion}

We have established and characterized an in vitro cell culture model for studying gonadotrophin secretion by pituitaries of non-human primates. With this model we have demonstrated the effects of $\mathrm{GnRH}$, inhibin and testosterone on isolated primate pituitary cells for the first time. To date, only a few reports have appeared on hormone secretion by the pituitary of non-human primates in vitro. They were based on tissue culture (Kohler et al. 1968, Nicoll et al. 1970) or cell culture (Bethea et al. 1988) and studied the secretion of prolactin and growth hormone in monkeys.

In humans, the experimental model of cultured pituitary cells has been used by several authors, but only for characterisation of secretion of thyroid stimulating hormone (Abrahamson et al. 1987), growth hormone (Markoff et al. 1986) and growth hormone and prolactin (Adams et al. 1981). Another model for human tissues is based on organ culture and has been used to study gonadotrophin secretion (Groom et al. 1971). Finally, tissue and dispersed cells from human pituitary adenomas have been cultured and used to examine gonadotrophin (Mashiter et al. 1981) and growth hormone (Le Dafniet et al. 1985) secretion. Tissue and organ culture of normal pituitaries are of limited value for investigating gonadotrophin secretion as uncontrollable hormone release results from central necrosis during long-term culture. Gonadotrophin secretion may also be altered in tissue or cells derived from pituitary adenomas. For these reasons our model of dispersed cells from normal pituitaries is probably the best in vitro system for studying gonadotrophin secretion.

We have been able to show for the first time that inhibin suppresses FSH secretion by pituitary cells of primates in vitro. The effect is the same as that in rat pituitary cells, as demonstrated in our study by pharmacological data from fitted dose-response curves. The $\mathrm{ED}_{50}$ values for suppression of FSH by inhibin in vitro were within the $95 \%$ range for inhibin in the serum of normal rhesus monkeys and rats as determined in previous studies (Fingscheidt et al. 1989, 1990, Chandolia et al. 1991). The dose-response curves for inhibin were of sigmoid shape, with the steepest part of the curve within the normal range of serum concentrations. Normal secretion of FSH may therefore be under constant suppression by inhibin. However, it must be taken into account that the RIA used for determination of inhibin in the serum of male monkeys reacts not only with the $31 \mathrm{kDa}$ form of inhibin, which was used in the in vitro experiments, but also with $59 \mathrm{kDa}$ inhibin and the $\alpha$-subunit precursor protein pro- $\alpha \mathrm{C}$. In our in vitro system, inhibin is a potent regulator of FSH at the pituitary.

Previous in vitro studies on the mode of action of inhibin at the pituitary were based on rat (Farnworth et al. 1988) and sheep (Clarke et al. 1993) pituitary cell cultures. In contrast with the rat, Muttukrishna \& Knight (1991) described a stimulating action of inhibin on LH in sheep, whereas the effects on FSH were similar in these two species with a greater sensitivity of the sheep pituitary cells to inhibin (Tsonis et al. 1986). The similarity of the effects of inhibin on FSH and LH as characterized by our rat and monkey pituitary cell culture systems underline the value 
of the rat model for understanding the physiology of the primate pituitary.

Previous in vivo experiments in male rhesus monkeys were based on a preparation known as the hypophysiotropic clamp. Hypothalami of these animals were lesioned and replaced with an invariant intermittent GnRH pump, thus eliminating components of the feedback system acting at the hypothalamic site. In this setting, immunoneutralization of inhibin led to selective hypersecretion of $\mathrm{FSH}$ with no effect on LH (Medhamurthy et al. 1990). Inhibin affected only FSH in rats, but had no effect on basal secretion of LH. This result is in contrast with a previous finding that both gonadotrophins were suppressed by inhibin in rats in vitro (Farnworth et al. 1988). This difference between two similar static culture systems in different laboratories remains unexplained. In dynamic in vitro models of superfused cells, however, a suppressive effect of inhibin could only be demonstrated for GnRHstimulated secretion of $\mathrm{LH}$, but not for basal release of $\mathrm{LH}$ (Kotsuji et al. 1988). These data support our results, since we only examined basal gonadotrophin release for effects of inhibin. In monkey pituitary cells, LH was not influenced by inhibin either, which is comparable with our data for rats.

Since only a limited number of pituitary cells was available for experiments, we decided to study doseresponses for two hormones, GnRH and inhibin. Testosterone was only applied in one dose, known to be maximally effective in rat pituitary cell cultures (Kitahara et al. 1991). The concentration chosen for testosterone is equivalent to double the upper normal range in normal male monkeys (Weinbauer et al. 1986, Winters et al. 1992). In contrast with the reported stimulating action of testosterone on FSH in rat pituitary cell cultures (Kitahara et al. 1991, Winters et al. 1992), we found no effect of testosterone at the dose of $10^{-7} \mathrm{M}$ on basal or GnRHstimulated secretion of FSH in monkeys. In vivo data in monkeys provide increasing evidence for the view that testosterone has no effect on FSH at the pituitary (Dubey et al. 1987, Abeyawardene \& Plant 1989, Medhamurthy et al. 1991, Majumdar et al. 1995) and that inhibin is the testicular hormone responsible for regulation of FSH at the pituitary site.

No significant effect of testosterone on either basal or GnRH-stimulated release of LH could be demonstrated in our monkey pituitary cell culture system. This result parallels the observations of others on rat pituitary cell cultures (Gharib et al. 1990, Winters et al. 1992), although some authors were able to demonstrate an inhibitory effect of testosterone on $\mathrm{GnRH}$-stimulated $\mathrm{LH}$ release in rats (Liang et al. 1984). Again, in vivo data for monkeys support our in vitro data. After castration, only a slight increase in LH was seen in monkeys with a hypophysiotropic clamp, instead of the dramatic postcastration hypersecretion of $\mathrm{LH}$ in animals with intact hypothalami (Plant \& Dubey 1984). Adams et al. (1988) demonstrated, in contrast with our findings, that testosterone increases $\mathrm{GnRH}$-stimulated $\mathrm{LH}$ release in prepubertal male monkeys. They suggested that the pituitary might be a target for the feedback action of testosterone on LH. Winters et al. (1992) found contradictory results when measuring production of mRNA for subunits of gonadotrophins. Both suppressing and stimulating effects of testosterone were found. In a more recent study, GnRH-stimulated FSH $\beta$ mRNA levels were found to be suppressed by testosterone in mouse pituitary cell cultures and transgenic hypogonadal mice (Kumar \& Low 1995).

The hypothalamus is supposed to be one site for the feedback action of testosterone in human males (Kerrigan et al. 1994). However, an additional site of action of testosterone at the pituitary was proposed by Finkelstein et al. (1991) and by Sheckter et al. (1989). These in vivo studies are limited by a possible effect of testosterone on remaining endogenous $\mathrm{GnRH}$ and do not represent an ideal model for studying effects at the pituitary level.

The dose-response characteristics of the action of $\mathrm{GnRH}$ on the release of gonadotrophins in our monkey pituitary cell culture system revealed that $\mathrm{LH}$ and $\mathrm{FSH}$ were stimulated by GnRH in the same manner, with equal mean effective doses, but the extent to which secretion could be stimulated beyond basal values differed greatly. LH could be stimulated tenfold whereas FSH was only stimulated threefold. In addition, a supply of fresh medium after $44 \mathrm{~h}$ increased the secretion rate for $\mathrm{LH}$ sevenfold compared with threefold for FSH. The in vitro secretion of FSH appears to occur more independently of culture conditions and GnRH stimulation than that of $\mathrm{LH}$. This underlines the relative importance of inhibin as the major feedback hormone for FSH.

We conclude that the pituitary is the target organ for inhibin in selectively controlling FSH in non-human primates. Comparing dose-response curves for inhibin with the inhibin concentration in the serum of monkeys suggests that the physiological secretion of FSH may be constantly suppressed by inhibin. Testosterone had no effect in our in vitro system and therefore the feedback mechanism of this steroid may be mediated exclusively via the hypothalamus.

\section{Acknowledgements}

The authors thank Professor D M de Kretser (Institute of Reproduction and Development, Monash University, Clayton, Victoria, Australia) and Dr D M Robertson (Prince Henry's Institute of Medical Research, Monash Medical Centre, Clayton, Victoria, Australia) for supplying purified inhibin. We are most thankful to $\mathrm{R}$ Sandhowe, M Heuermann and G Stelke for their excellent technical assistance. Parts of this work were presented at the Second Pituitary Congress, Palm Springs, CA, USA in 1989. The study was supported in part by the Deutsche 
Forschungsgemeinschaft (DFG) (grants Fi 465/1-1 and Ni 130/11-1 (A1)).

\section{References}

Abeyawardene SA \& Plant TM 1989 Bilateral orchidectomy and concomitant testosterone replacement in the juvenile male rhesus monkey (Macaca mulatta) receiving an invariant intravenous gonadotropin-releasing hormone $(\mathrm{GnRH})$ infusion results, as in the hypothalamus lesioned GnRH-driven adult male, in a selective hypersecretion of follicle-stimulating hormone. Endocrinology 125 257-259.

Abrahamson MJ, Wormald PJ \& Millar RP 1987 Neuroendocrine regulation of thyrotropin release in cultured human pituitary cells. Journal of Clinical Endocrinology and Metabolism 65 1159-1163.

Adams EF, Brajkovich IE \& Mashiter K 1981 Growth hormone and prolactin secretion by dispersed cell cultures of a normal human pituitary: effects of thyrotrophin releasing hormone, theophylline, somatostatin, and 2-bromo-alpha-ergocryptine. Acta Endocrinologica 98 345-351.

Adams LA, Clifton DK, Bremner WJ \& Steiner RA 1988 Testosterone modulates the differential release of luteinizing hormone and follicle-stimulating hormone that occurs in response to changing gonadotropin-releasing hormone pulse frequency in the male monkey, Macaca fascicularis. Biology of Reproduction 38 156-162.

Bagatell CJ, Dahl KD \& Bremner WJ 1994 The direct pituitary effect of testosterone to inhibit gonadotropin secretion in men is partially mediated by aromatization to estradiol. Journal of Andrology $\mathbf{1 5}$ $15-21$.

Bethea CL, Sprangers SA, West NB \& Brenner RM 1988 The effect of simultaneous versus sequential estradiol and progesterone treatments on prolactin production in monkey pituitary cell cultures. Endocrinology 122 1786-1800.

Chandolia RK, Weinbauer GF, Fingscheidt U, Bartlett JM \& Nieschlag E 1991 Effects of flutamide on testicular involution induced by an antagonist of gonadotrophin-releasing hormone and on stimulation of spermatogenesis by follicle-stimulating hormone in rats. Journal of Reproduction and Fertility 93 313-323.

Clarke IJ, Rao A, Fallest PC \& Shupnik MA 1993 Transcription rate of the follicle stimulating hormone (FSH) beta subunit gene is reduced by inhibin in sheep but this does not fully explain the decrease in mRNA. Molecular and Cellular Endocrinology $\mathbf{9 1}$ 211-216.

Dubey AK, Zeleznik AJ \& Plant TM 1987 In the rhesus monkey (Macaca mulatta), the negative feedback regulation of folliclestimulating hormone secretion by an action of testicular hormone directly at the level of the anterior pituitary gland cannot be accounted for by either testosterone or estradiol. Endocrinology 121 2229-2237.

Farnworth PG, Robertson DM, de Kretser DM \& Burger HG 1988 Effects of 31 kilodalton bovine inhibin on follicle-stimulating hormone and luteinizing hormone in rat pituitary cells in vitro: actions under basal conditions. Endocrinology 122 207-213.

Fingscheidt U, Weinbauer GF, Robertson DM, de Kretser DM \& Nieschlag E 1989 Radioimmunoassay of inhibin in the serum of male monkeys. Journal of Endocrinology 122 477-483.

Fingscheidt U, Weinbauer GF, Khan SA \& Nieschlag E 1990 Follicle-stimulating hormone stimulates inhibin in the serum of male monkeys (Macaca mulatta). Acta Endocrinologica 122 96-100.

Finkelstein JS, O'Dea LS, Whitcomb RW \& Crowley WF Jr 1991 Sex steroid control of gonadotropin secretion in the human male. I. Effects of testosterone administration in normal and gonadotropinreleasing hormone-deficient men. Journal of Clinical Endocrinology and Metabolism 73 621-628.

Forage RG, Ring JM, Brown RW, McInerney BV, Cobon GS, Gregson RP, Robertson DM, Morgan FJ, Hearn MTW, Findlay
JK, Wettenhall REH, Burger HG \& de Kretser DM 1986 Cloning and sequence analysis of cDNA species coding for the two subunits of inhibin from bovine follicular fluid. Proceedings of the National Academy of Sciences of the USA 83 3091-3095.

Gharib SD, Leung PC, Carroll RS \& Chin WW 1990 Androgens positively regulate follicle-stimulating hormone beta-subunit mRNA levels in rat pituitary cells. Molecular Endocrinology 4 $1620-1626$.

Groom GV, Groom MA, Cooke ID \& Boyns AR 1971 The secretion of immuno-reactive luteinizing hormone and follicle-stimulating hormone by the human foetal pituitary in organ culture. Journal of Endocrinology 49 335-344.

Hyde CL, Childs G, Wahl LM, Naor Z \& Catt KJ 1982 Preparation of gonadotroph-enriched cell populations from adult rat anterior pituitary cells by centrifugal elutriation. Endocrinology 111 1421-1423.

Kamel F, Balz JA, Kubajak CL \& Schneider VA 1987 Gonadal steroids modulate pulsatile luteinizing hormone secretion by perifused rat anterior pituitary cells. Endocrinology 120 1651-1657.

Kerrigan JR, Veldhuis JD \& Rogol AD 1994 Androgen-receptor blockade enhances pulsatile luteinizing hormone production in late pubertal males: evidence for a hypothalamic site of physiologic androgen feedback action. Pediatric Research 35 102-106.

Khan SA \& Diczfalusy E 1983 Heterologous radioimmunoassay for monkey gonadotrophins. Asessment of the reagents proposed for the assay of FSH. Acta Endocrinologica 104 15-22.

Kitahara S, Kotsuji F, Keeping HS, Oshima H, Troen P \& Winters SJ 1991 Interrelationship between the actions of testosterone and primate Sertoli cell inhibin in the control of gonadotropin secretion by cultured pituitary cells. Endocrinology 128 710-716.

Kohler PO, Bridson WE \& Rayford PL 1968 Cortisol stimulation of growth hormone production by monkey adenohypophysis in tissue culture. Biochemical and Biophysical Research Communications 33 834-840.

Kotsuji F, Winters SJ, Keeping HS, Attardi B, Oshima H \& Troen P 1988 Effects of inhibin from primate Sertoli cells on folliclestimulating hormone and luteinizing hormone release by perifused rat pituitary cells. Endocrinology 122 2796-2802.

Kreysing P \& Nieschlag E 1987 Direct chemiluminescence assay for testosterone. In Bioluminescence and Chemiluminescence. New Perspectives, pp 269-272. Eds J Schölmerich, R Andreesen, A Kap, M Ernst \& WG Wood. Chichester: Wiley and Sons.

Kumar TR \& Low MJ 1995 Hormonal regulation of human follicle-stimulating hormone-beta subunit gene expression: $\mathrm{GnRH}$ stimulation and GnRH-independent androgen inhibition. Neuroendocrinology 61 628-637.

Kurshid S, Weinbauer GF \& Nieschlag E 1991 Effects of administration of testosterone and gonadotrophin-releasing hormone $(\mathrm{GnRH})$ antagonist on basal and $\mathrm{GnRH}$-stimulated gonadotrophin secretion in orchidectomized monkeys. Journal of Endocrinology 129 363-370.

Le Dafniet M, Garnier P, Brandi AM, Bression D, Scherrer H, Racadot J \& Peillon F 1985 Interaction between somatostatin and $\mathrm{TRH}$ on growth hormone secretion in perifused human growth hormone tumor cells. Hormone Research 21 235-239.

Liang T, Brady EJ, Cheung A \& Saperstein R 1984 Inhibition of luteinizing hormone (LH)-releasing hormone-induced secretion of LH in rat anterior pituitary cell culture by testosterone without conversion to 5 alpha-dihydrotestosterone. Endocrinology 115 2311-2317.

Majumdar SS, Mikuma N, Ishwad PC, Winters SJ, Attardi BJ, Perera AD \& Plant TM 1995 Replacement with recombinant human inhibin immediately after orchidectomy in the hypophysiotropically clamped male rhesus monkey (Macaca mulatta) maintains follicle-stimulating hormone (FSH) secretion and FSH beta messenger ribonucleic acid levels at precastration values. Endocrinology 136 1969-1977. 
Markoff E, Lee DW, Culler FL, Jones KL \& Lewis UJ 1986 Release of the 22000 - and the 20000 -dalton variants of growth hormone in vivo and in vitro by human anterior pituitary cells. Journal of Clinical Endocrinology and Metabolism 62 664-669.

Mashiter K, Adams E \& Van Noorden S 1981 Secretion of LH, FSH, and PRL shown by cell culture and immunocytochemistry of human functionless pituitary adenomas. Clinical Endocrinology 15 103-112.

Mason AJ, Hayflick JS, Ling N, Esch J, Ueno N, Ying SY, Guillemin R, Niall H \& Seeburg PH 1985a Complementary DNA sequences of ovarian follicular fluid inhibin show precursor structure and homology with transforming growth factor- $\beta$. Nature 318 659-663.

Mason AJ, Niall HD \& Seeburg PH $1985 b$ Structure of two human ovarian inhibins. Biochemical and Biophysical Research Communications 135 957-964.

Mayo KE, Cerelli GM, Spiess J, Rivier J, Rosenfeld MG, Evans RM \& Vale W 1986 Inhibin A-subunit cDNAs from porcine ovary and human placenta. Proceedings of the National Academy of Sciences of the USA 83 5849-5853.

Medhamurthy R, Abeyawardene SA, Culler MD, Negro Vilar A \& Plant TM 1990 Immunoneutralization of circulating inhibin in the hypophysiotropically clamped male rhesus monkey (Macaca mulatta) results in a selective hypersecretion of follicle-stimulating hormone. Endocrinology 126 2116-2124.

Medhamurthy R, Culler MD, Gay VL, Negro Vilar A \& Plant TM 1991 Evidence that inhibin plays a major role in the regulation of follicle-stimulating hormone secretion in the fully adult male rhesus monkey (Macaca mulatta). Endocrinology 129 389-395.

Mercer JE, Clements JA, Funder JW \& Clarke IJ 1987 Rapid and specific lowering of pituitary FSH beta mRNA levels by inhibin. Molecular and Cellular Endocrinology 53 251-254.

Muttukrishna S \& Knight PG 1991 Inverse effects of activin and inhibin on the synthesis and secretion of FSH and LH by ovine pituitary cells in vitro. Journal of Molecular Endocrinology 6 171-178.

Nicoll CS, Parsons JA, Fiorindo RP, Nichols CW Jr \& Sakuma M 1970 Evidence of independent secretion of prolactin and growth hormone in vitro by adenohypophyses of rhesus monkeys. Journal of Clinical Endocrinology and Metabolism 30 512-519.

Plant TM \& Dubey AK 1984 Evidence from the rhesus monkey (Macaca mulatta) for the view that negative feedback control of luteinizing hormone secretion by the testis is mediated by a deceleration of hypothalamic gonadotropin-releasing hormone pulse frequency. Endocrinology 115 2145-2153.
Rivier C, Corrigan A \& Vale W 1991 Effect of recombinant human inhibin on gonadotropin secretion by the male rat. Endocrinology 129 2155-2159.

Robertson DM, deVos FL, Foulds LM, McLachlan RI, Burger HG, Morgan FJ, Hearn MT \& deKretser DM 1986 Isolation of a $31 \mathrm{kDa}$ form of inhibin from bovine follicular fluid. Molecular and Cellular Endocrinology 44 271-277.

Scott RS, Burger HG \& Quigg H 1980 A simple and rapid in vitro bioassay for inhibin. Endocrinology 107 1536-1542.

Sheckter CB, Matsumoto AM \& Bremner WJ 1989 Testosterone administration inhibits gonadotropin secretion by an effect directly on the human pituitary. Journal of Clinical Endocrinology and Metabolism 68 397-401.

Solano AR, Dufau L \& Catt KJ 1979 Bioassay and radioimmunoassay of serum luteinizing hormone in the male rat. Endocrinology 105 372-381.

Stouffer RL, Dahl KD, Hess DL, Woodruff TK, Mather JP \& Molskness TA 1994 Systemic and intraluteal infusion of inhibin A or activin A in rhesus monkeys during the luteal phase of the menstrual cycle. Biology of Reproduction 50 888-895.

Tilbrook AJ, de Kretser DM \& Clarke IJ 1993 Human recombinant inhibin A and testosterone act directly at the pituitary to suppress plasma concentrations of FSH in castrated rams. Journal of Endocrinology 138 181-189.

Tsonis CG, McNeilly AS \& Baird DT 1986 Measurement of exogenous and endogenous inhibin in sheep serum using a new and extremely sensitive bioassay for inhibin based on inhibition of ovine pituitary FSH secretion in vitro. Journal of Endocrinology 110 341-352.

Weinbauer GF, Surmann FJ, Akhtar FB, Shah GV, Vickery BH \& Nieschlag E 1984 Reversible inhibition of testicular function by a gonadotropin hormone-releasing hormone antagonist in monkeys (Macaca fascicularis). Fertility and Sterility 42 906-914.

Weinbauer GF, Marshall GR \& Nieschlag E 1986 New injectable testosterone ester maintains serum testosterone of castrated monkeys in the normal range for four months. Acta Endocrinologica 113 $128-132$.

Winters SJ, Ishizaka K, Kitahara S, Troen P \& Attardi B 1992 Effects of testosterone on gonadotropin subunit messenger ribonucleic acids in the presence or absence of gonadotropin-releasing hormone. Endocrinology $130726-734$.

Received 29 January 1998

Accepted 26 May 1998 